\title{
Thermal Expansion of Scheelite-Like Molybdate Powders and Ceramics
}

\author{
M. G. Tokarev ${ }^{a}$, E. A. Potanina ${ }^{a,}$ *, A. I. Orlova $a$, S. A. Khainakov ${ }^{b}$, M. S. Boldin ${ }^{a}$, E. A. Lantsev ${ }^{a}$, \\ N. V. Sakharov ${ }^{a}$, A. A. Murashov ${ }^{a}$, S. Garcia-Granda ${ }^{b}$, A. V. Nokhrin ${ }^{a}$, and V. N. Chuvil'deev ${ }^{a}$ \\ ${ }^{a}$ Lobachevsky State University, pr. Gagarina 23, Nizhny Novgorod, 603950 Russia \\ ${ }^{b}$ University of Oviedo, Calle San Francisco 1, 33003, Oviedo, Spain \\ *e-mail: Ekaterina.potanina@list.ru
}

Received May 23, 2018; revised February 10, 2019; accepted February 12, 2019

\begin{abstract}
Na}_{x} \mathrm{Sr}_{1-2 x} \mathrm{Nd}_{x} \mathrm{MoO}_{4}(x=0-0.5, \Delta x=0.1)$ solid solutions with the scheelite structure have been synthesized for the first time and their crystallographic parameters have been determined as functions of composition and temperature. Their thermal expansion coefficients have been determined in the temperature range $25-1000^{\circ} \mathrm{C}: \alpha_{a}=(12.9-14.9) \times 10^{-6}{ }^{\circ} \mathrm{C}^{-1}$ and $\alpha_{c}=(24.9-25.9) \times 10^{-6}{ }^{\circ} \mathrm{C}^{-1}$. Using spark plasma sintering at $t_{\max } \approx 872-985^{\circ} \mathrm{C}$ and $\tau \approx 650-750 \mathrm{~s}$, we have prepared ceramics with relative densities in the range 97-99\%.
\end{abstract}

Keywords: scheelite, strontium, neodymium, waste, spark plasma sintering

DOI: $10.1134 / \mathrm{S} 0020168519070203$

\section{INTRODUCTION}

Improving radioactive waste (RAW) safety is a priority issue in the modern nuclear industry. Enhancing the performance of existing materials and designing novel materials with excellent service characteristics needed for high-level waste management should help to reduce the risk of radionuclides reaching the environment. In this context, it is promising to use crystalline mineral-like waste forms, implementing "naturelike" technologies.

Among such crystalline forms, structural analogs of scheelite $\left(\mathrm{CaWO}_{4}\right)$ group minerals, in particular, molybdates, warrant special attention.

Molybdenum has attracted research interest as a potential fuel rod cladding material capable of replacing zirconium [1], which is at present widely used for this purpose and suffers from the following drawbacks: (1) It can actively react with water to form hydrogen at temperatures above $700^{\circ} \mathrm{C}$, which is extremely dangerous in the case of nuclear power plant accidents; (2) It reacts with overheated uranium dioxide in nuclear fuel, which leads to additional heat release and lowers the melting point of the fuel, thus contributing to the overheating and melting of the reactor core of the nuclear power plant [2,3]. The use of Mo instead of $\mathrm{Zr}$ in the above-mentioned constructions will lead to the formation of a new type of Mo-containing waste.
Brinkman et al. [4] studied molybdates with the powellite structure, similar to the scheelite structure, for the immobilization of Mo-rich nuclear waste. Such crystalline waste forms can also include lanthanides and actinides [5].

In nature, scheelite crystallizes in tetragonal symmetry (sp. gr. $I 4_{1} / a$ ). Its crystal structure is made up of $\mathrm{CaO}_{8}$ and $\mathrm{WO}_{4}$ polyhedra, which share oxygen vertices [6].

Characteristically, compounds with such structure exhibit broad isovalent and heterovalent isomorphism. According to Evdokimov et al. [7], the Ca cations can be partially or fully replaced by $\mathrm{Sr}, \mathrm{Cu}, \mathrm{Mn}, \mathrm{Fe}, \mathrm{Ba}$, rare-earth ( $\mathrm{Nd}, \mathrm{Pm}, \mathrm{Sm}, \mathrm{Eu}), \mathrm{Cr}, \mathrm{Nb}$, and Ta cations, and the $\mathrm{W}$ cations can be replaced by Mo, Ge, V, Ir, and Re. Extensive studies have been concerned with scheelite-structure compounds containing cations: $\mathrm{K}$ and $\mathrm{La}-\mathrm{Lu}$ [8]; $\mathrm{Ca}, \mathrm{Sr}, \mathrm{Ba}$, and REE [9]; alkalineearth metals and $\mathrm{Pm}[10,11]$; $\mathrm{Li}, \mathrm{Na}$, and $\mathrm{Np}$ [12]; $\mathrm{Na}$ and $\mathrm{U}(\mathrm{IV})$ [13]; K, Rb, Cs, Nd, Pu, and $\mathrm{Am}$ [14]; Li, $\mathrm{Na}$, and $\mathrm{Pu}$ [15]; Li, K, La, Nd, Dy, and Er [16]; Li, $\mathrm{Rb}$, and REE [17]; Li, K, Rb, Tl, and Nd [18]; Li, Tl, and REE [19]; K, Cu, Ho, Gd, and Tb [20, 21]; and $\mathrm{Li}, \mathrm{Ba}, \mathrm{Gd}$, and Tm [22]. All of the systems studied contain either individual compounds $(\mathrm{Ca}, \mathrm{Sr}, \mathrm{Ba}$, and rare-earth tungstates and molybdates) or solid solutions with two types of cations: (1) alkali and alkalineearth metals, (2) alkali metals and $f$-elements (rare 
earths and uranium), and (3) alkaline-earth and rareearth metals.

The behavior of substances with the scheelite structure on heating has been better studied for individual compounds. Thermal expansion coefficients in the range $25-1000^{\circ} \mathrm{C}$ were reported to be $\alpha_{a}=13.5 \times$ $10^{-6}{ }^{\circ} \mathrm{C}^{-1}$ and $\alpha_{c}=22.8 \times 10^{-6}{ }^{\circ} \mathrm{C}^{-1}$ for $\mathrm{CaWO}_{4}, \alpha_{a}=$ $12.7 \times 10^{-6} \mathrm{~K}^{-1}$ and $\alpha_{c}=21.4 \times 10^{-6} \mathrm{~K}^{-1}$ for $\mathrm{CaMoO}_{4}, \alpha_{a}=11.4 \times 10^{-6}{ }^{\circ} \mathrm{C}^{-1}$ for $\mathrm{SrMoO}_{4}$, and $\alpha_{a}$ $=9.38 \times 10^{-6} \mathrm{~K}^{-1}$ for $\mathrm{BaMoO}_{4}$. The studied tungstates and molybdates are classified as materials with a large linear thermal expansion coefficients (LTECs).

It should be taken into account that powder samples are not reliable forms for radioactive waste disposal. In this work, we propose placing polycrystalline compounds into ceramic matrices. In such a case, the sintering method is an important issue. Pang et al. [25, 26] prepared ceramics with the compositions $\mathrm{K}_{0.5} \mathrm{La}_{0.5} \mathrm{MoO}_{4}$ and $\mathrm{Li}_{0.5} \mathrm{Ln}_{0.5} \mathrm{MoO}_{4}(\mathrm{Ln}=\mathrm{Nd}, \mathrm{Er}, \mathrm{Gd}$, $\mathrm{Y}, \mathrm{Yb}, \mathrm{Sm}, \mathrm{Ce}$ ) by uniaxial cold pressing followed by firing in the range $560-720^{\circ} \mathrm{C}$ for 2 or $5 \mathrm{~h}$, which ensured relative densities $\rho_{\text {rel }}=93-95 \%$.

Conditions for the fabrication of ceramics by spark plasma sintering (SPS), a method used in this study, can be varied widely. In particular, the sintering process can be run at high pressures and relatively low temperatures for a short time, which makes it possible to produce ceramics from materials with low decomposition temperatures and volatile compounds having high-temperature phase transitions [27, 28].

In designing materials for nuclear waste consolidation into crystalline matrices, an important issue is to have data on the formation of solid solutions with compositions more complex than those described above, their behavior on heating, and the feasibility of producing dense ceramics from such materials.

This work is a step in this direction. Our purpose was to prepare and characterize molybdate solid solutions with the scheelite structure in which alkali, alkaline-earth, and rare-earth metals ( $\mathrm{Na}, \mathrm{Sr}$, and $\mathrm{Nd}$ ) can be present together. In these materials, $\mathrm{Sr}$ and $\mathrm{Nd}$ imitate nuclear decay products. In addition, $\mathrm{Nd}$ imitates minor actinides.

In this paper, we report the synthesis of $\mathrm{Na}_{x} \mathrm{Sr}_{1-2 x^{-}}$ $\mathrm{Nd}_{x} \mathrm{MoO}_{4}(x=0-0.5, \Delta x=0.1)$ solid solutions, their composition stability limits, their behavior on heating, and the preparation and characterization of ceramics based on these solid solutions.

\section{EXPERIMENTAL}

Synthesis of powders. Powders were prepared via coprecipitation in aqueous systems. Stoichiometric amounts of the starting chemicals $\mathrm{NaNO}_{3}, \mathrm{Sr}\left(\mathrm{NO}_{3}\right)_{2}$, and $\mathrm{Nd}\left(\mathrm{NO}_{3}\right)_{3} \cdot 6 \mathrm{H}_{2} \mathrm{O}$ were dissolved in water and then an $\left(\mathrm{NH}_{4}\right)_{6} \mathrm{Mo}_{7} \mathrm{O}_{24} \cdot 4 \mathrm{H}_{2} \mathrm{O}$ precipitant solution was added with constant stirring, leading to instantaneous precipitation. Stirring was continued for an additional $30 \mathrm{~min}$. The resultant suspension was held at $90^{\circ} \mathrm{C}$ for $10 \mathrm{~h}$. The dry residue was ground in an agate mortar for $20 \mathrm{~min}$ and then held at 500, 600, 700, 800,900 , and $1000^{\circ} \mathrm{C}$ for $15 \mathrm{~h}$ at each temperature. After each heat treatment step, we determined the phase composition of the materials and reground them in the agate mortar.

Preparation of ceramics. Ceramics were produced by SPS. The synthesized powders were placed in a graphite press die $10.8 \mathrm{~mm}$ in inner diameter and heated by high-power millisecond DC pulses (up to $3 \mathrm{kA}$ ). The temperature was monitored with a Chino IR-AH pyrometer focused on the surface of the graphite press die. The sintering process was run in vacuum (6 $\mathrm{Pa}$ ) at an applied uniaxial pressure of $\sim 70 \mathrm{MPa}$.

Methods and instruments. The elemental composition of the samples was determined by energy dispersive X-ray (EDX) spectroscopy on a JEOL JSM6610LV scanning electron microscope (JEOL Ltd., Japan).

The phase composition of the powders and ceramics was determined by X-ray diffraction on a Shimadzu LabX XRD-6000 X-ray diffractometer in the angular range $2 \theta=10^{\circ}-50^{\circ}$ with filtered $\mathrm{Cu} K_{\alpha}$ radiation $(\lambda=$ $1.54056 \AA)$.

High-temperature X-ray diffraction data were collected in the temperature range $25-1000^{\circ} \mathrm{C}$ and angular range $2 \theta=15^{\circ}-60^{\circ}$ on a Panalytical X'Pert Pro $\mathrm{X}$-ray diffractometer equipped with an Anton Paar HTK-1200N high-temperature chamber.

Ceramics were produced by sintering the powders in a Dr. SINTER Model SPS-625 spark plasma sintering system (SPS Syntex Inc. Ltd., Japan).

The density of the ceramics was determined by hydrostatic weighing in distilled water on a Sartorius CPA 225D balance.

\section{RESULTS AND DISCUSSION}

Powder samples. The synthesized samples had the form of microcrystalline powders lilac in color (except the $x=0$ powder, which was colorless).

The intended and experimentally determined $x$ values (Table 1) differed insignificantly. 
Table 1. Intended and experimentally determined elemental compositions of the $\mathrm{Na}_{x} \mathrm{Sr}_{1-2 x} \mathrm{Nd}_{x} \mathrm{MoO}_{4}$ samples

\begin{tabular}{c|c|c|c}
\hline$x$ & $\mathrm{Na}, x$ & $\mathrm{Sr}, 1-2 x$ & $\mathrm{Nd}, x$ \\
\hline calculation & \multicolumn{3}{|c}{ experiment } \\
\hline 0 & 0 & 1 & 0 \\
0.1 & 0.11 & 0.78 & 0.11 \\
0.2 & 0.20 & 0.60 & 0.20 \\
0.3 & 0.29 & 0.42 & 0.29 \\
0.4 & 0.41 & 0.18 & 0.41 \\
0.5 & 0.5 & 0 & 0.5 \\
\hline
\end{tabular}

$\mathrm{X}$-ray diffraction characterization after heat treatment showed that single-phase $\mathrm{Na}_{x} \mathrm{Sr}_{1-2 x} \mathrm{Nd}_{x} \mathrm{MoO}_{4}$ $(x=0-0.5)$ products were obtained at $800^{\circ} \mathrm{C}$ and that their composition persisted after heat treatment at $1000^{\circ} \mathrm{C}$ for $15 \mathrm{~h}$. Figure 1 shows $\mathrm{X}$-ray diffraction patterns of the $\mathrm{Na}_{0.1} \mathrm{Sr}_{0.8} \mathrm{Nd}_{0.1} \mathrm{MoO}_{4}$ sample after all heat treatment steps. Similar results were obtained for the other compositions. Figure 2 shows X-ray diffraction patterns of the samples after heat treatment at $800^{\circ} \mathrm{C}$.

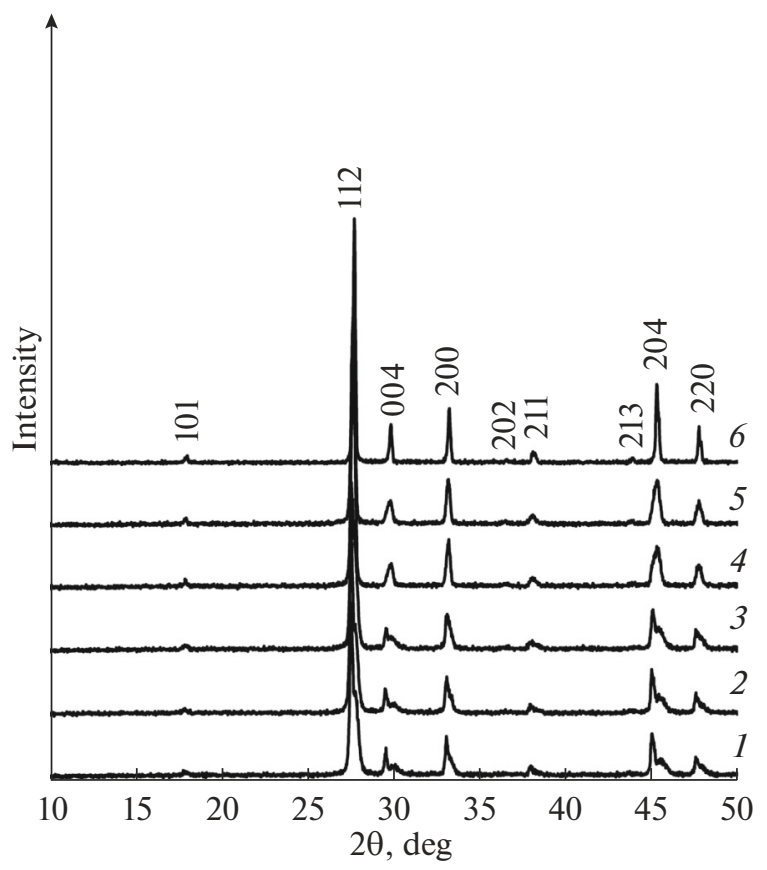

Fig. 1. $\mathrm{X}$-ray diffraction patterns of the $\mathrm{Na}_{0.1} \mathrm{Sr}_{0.8} \mathrm{Nd}_{0.1} \mathrm{MoO}_{4}$ powder after heat treatment at (1) $500,(2) 600,(3) 700,(4) 800,(5) 900$, and (6) $1000^{\circ} \mathrm{C}$.
The powders had the scheelite structure, space group $I 4_{1} / a$ (analogues in the ICDD database: $\mathrm{SrMoO}_{4}$, no. $08-0482 ; \mathrm{Na}_{0.5} \mathrm{Nd}_{0.5} \mathrm{MoO}_{4}$, no. 25-0852).

Figure 3 shows composition dependences of the $a$ and $c$ cell parameters for the $\mathrm{Na}_{x} \mathrm{Sr}_{1}-{ }_{2 x} \mathrm{Nd}_{x} \mathrm{MoO}_{4}$ samples. The unit-cell parameters vary linearly over the entire $x$ range studied. With increasing $x$, both $a$ and $c$ decrease.

Thus, the system under study contains a solid solution series due to $2 \mathrm{Sr}^{2+} \rightleftarrows \mathrm{Na}^{+}+\mathrm{Nd}^{3+}$ heterovalent isomorphous substitutions.

The behavior of the $\mathrm{Na}_{x} \mathrm{Sr}_{1-2 x} \mathrm{Nd}_{x} \mathrm{MoO}_{4}(x=0$, $0.1,0.2,0.3,0.4,0.5)$ samples on heating was studied by high-temperature $\mathrm{X}$-ray diffraction in the temperature range from 25 to $1000^{\circ} \mathrm{C}$. The temperature dependences of the calculated unit-cell parameters, $a(t)$ and $c(t)$, in Fig. 4 demonstrate that they increase monotonically with temperature.

The axial $\left(\alpha_{a}\right.$ and $\left.\alpha_{c}\right)$ and average $\left(\alpha_{a v}\right)$ LTECs of the molybdates and thermal expansion anisotropy $(\Delta \alpha)$ in them are presented in Table 2.

These data demonstrate that the molybdates under study have high LTEC values, approaching those reported for the $\mathrm{SrMoO}_{4}$ molybdate [24].

Ceramic samples. Using the SPS of the $\mathrm{Na}_{x} \mathrm{Sr}_{1-2 x^{-}}$ $\mathrm{Nd}_{x} \mathrm{MoO}_{4}(x=0,0.1,0.2,0.3,0.4,0.5)$ powders, we

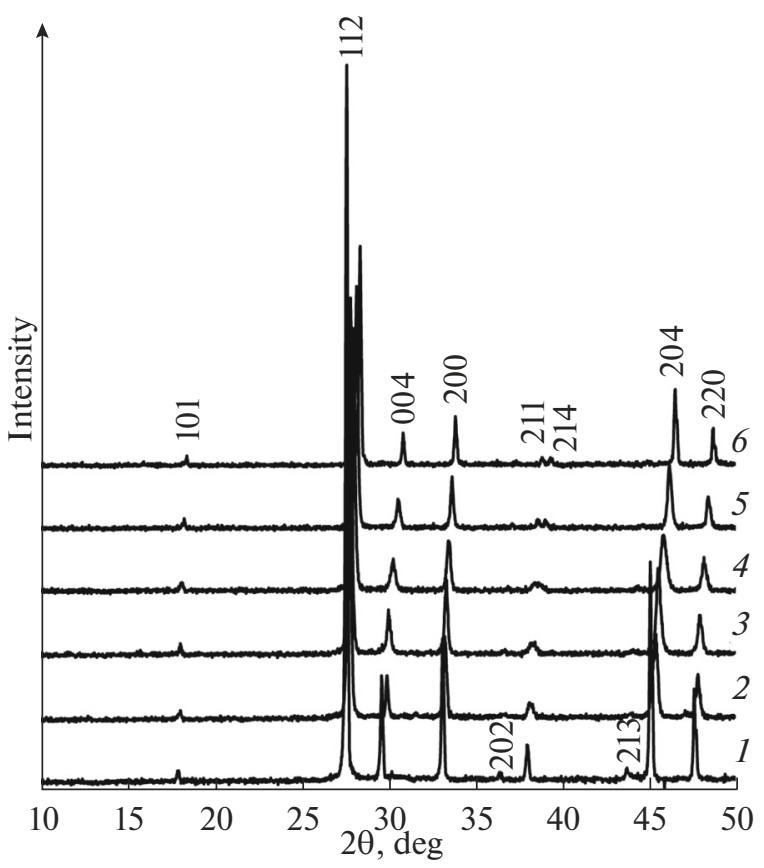

Fig. 2. X-ray diffraction patterns of the $\mathrm{Na}_{x} \mathrm{Sr}_{1}-2 x \mathrm{Nd}_{x} \mathrm{MoO}_{4}$ powders with $x=(1) 0$, (2) 0.1 , (3) 0.2 , (4) 0.3, (5) 0.4 , and (6) 0.5 after heat treatment at $800^{\circ} \mathrm{C}$ for $15 \mathrm{~h}$. 


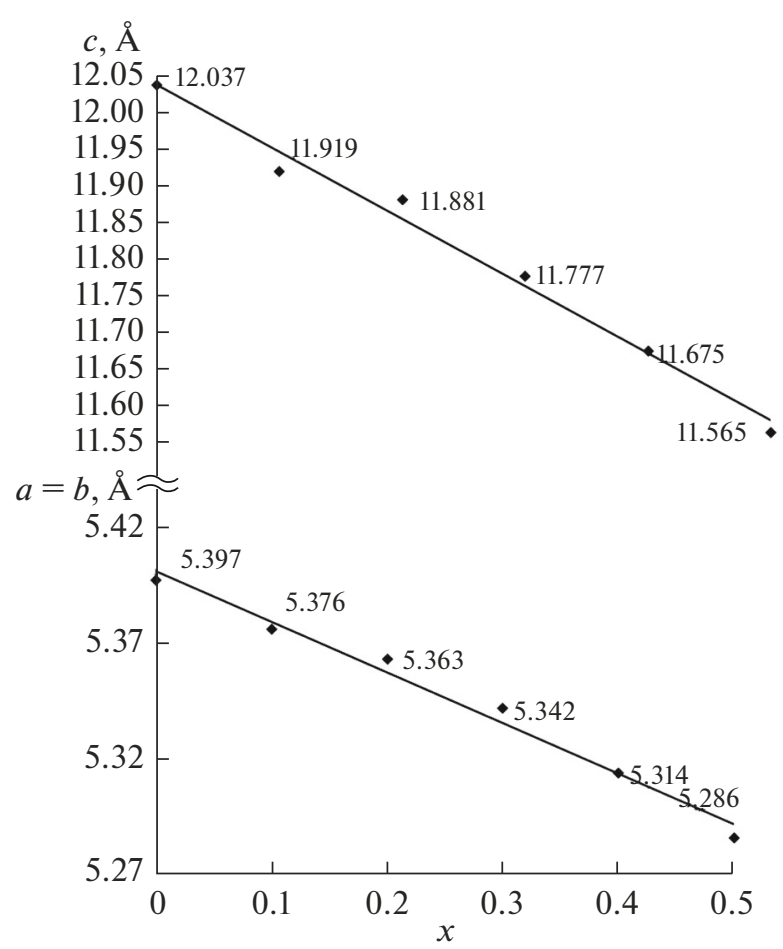

Fig. 3. Composition dependences of the $a$ and $c$ cell parameters for the $\mathrm{Na}_{x} \mathrm{Sr}_{1-2 x} \mathrm{Nd}_{x} \mathrm{MoO}_{4}$ samples.

prepared ceramic samples. The corresponding sintering diagrams are presented in Fig. 5. The sintering conditions and the measured and relative densities of the ceramics are summarized in Table $3: t_{\max } \approx 872-$ $985^{\circ} \mathrm{C}, \tau \approx 650-750 \mathrm{~s}, \rho_{\text {rel }} \approx 97-99 \%$.

Table 2. Thermal expansion coefficients and anisotropy of the $\mathrm{Na}_{x} \mathrm{Sr}_{1-2 x} \mathrm{Nd}_{x} \mathrm{MoO}_{4}$ molybdates

\begin{tabular}{c|c|c|c|c}
\hline \multirow{2}{*}{$x$} & \multicolumn{4}{|c}{$\alpha \times 10^{6},{ }^{\circ} \mathrm{C}^{-1}$} \\
\cline { 2 - 5 } & $\alpha_{a}$ & $\alpha_{c}$ & $\alpha_{\mathrm{av}}$ & $\Delta \alpha$ \\
\hline 0 & 12.9 & 24.9 & 18.9 & 12.0 \\
0.1 & 13.0 & 25.1 & 19.1 & 12.1 \\
0.2 & 13.0 & 25.2 & 19.1 & 12.2 \\
0.3 & 14.9 & 25.4 & 20.2 & 10.5 \\
0.4 & 13.1 & 25.5 & 19.3 & 12.4 \\
0.5 & 13.2 & 25.9 & 19.6 & 12.7 \\
\hline
\end{tabular}

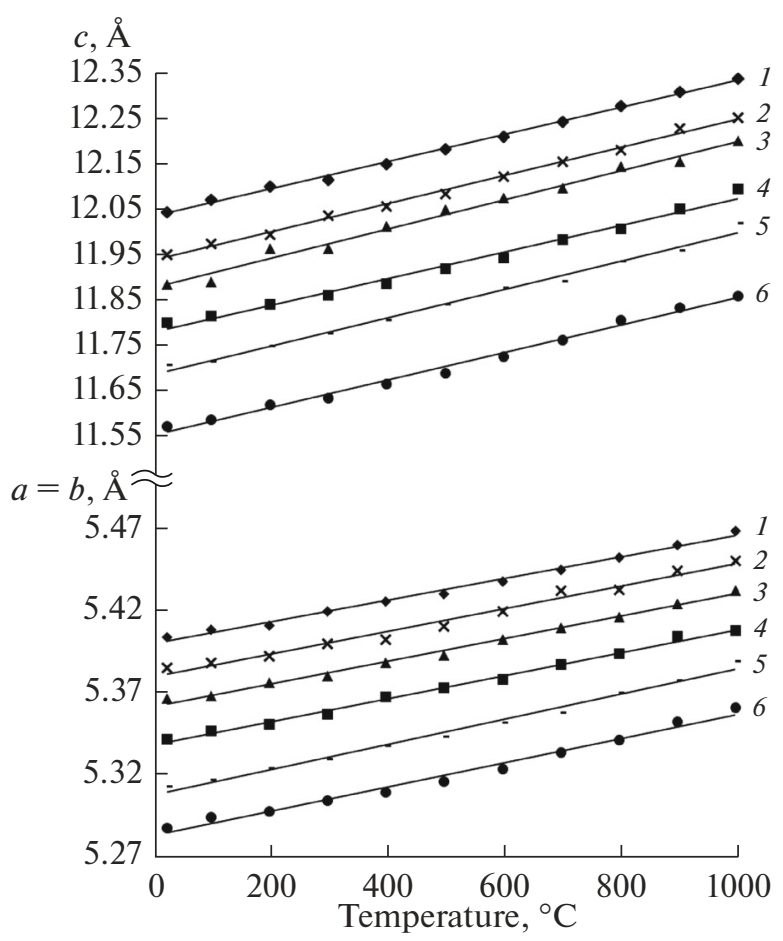

Fig. 4. Temperature dependences of the $a$ and $c$ cell parameters for the $\mathrm{Na}_{x} \mathrm{Sr}_{1-2 x} \mathrm{Nd}_{x} \mathrm{MoO}_{4}$ samples with $x=$ (1) 0, , (2) 0.1, (3) 0.2, (4) 0.3 , (5) 0.4 , and (6) 0.5 .

The X-ray diffraction patterns in Fig. 6 demonstrate that the ceramic samples are identical in phase composition to the starting powders.

Thus, we have extended knowledge of the family of Mo-containing phases with the scheelite structure and obtained new data on the behavior of molybdates with a complex cation composition on heating. SPS has been shown to be a promising process for sintering Mo-containing materials.

\section{CONCLUSIONS}

$\mathrm{Na}_{x} \mathrm{Sr}_{1-2 x} \mathrm{Nd}_{x} \mathrm{MoO}_{4}$ solid solutions exist over the entire composition range studied: $x=0-0.5$. Their unit-cell parameters vary monotonically with $\mathrm{x}$. Evaluation of their thermal stability has shown that the synthesized powder samples retain their phase composition after heat treatment at $1000^{\circ} \mathrm{C}$. Their thermal expansion coefficients have been determined in the temperature range $25-1000^{\circ} \mathrm{C}: \alpha_{a}=(12.9-14.9) \times$ $10^{-6}{ }^{\circ} \mathrm{C}^{-1}$ and $\alpha_{c}=(24.9-25.9) \times 10^{-6}{ }^{\circ} \mathrm{C}^{-1}$. We have obtained ceramics with $\rho_{\text {rel }} \approx 97-99 \%$.

The present results demonstrate that molybdenum-containing scheelite-like crystalline materials can be used as matrices for the immobilization of RAW components. 

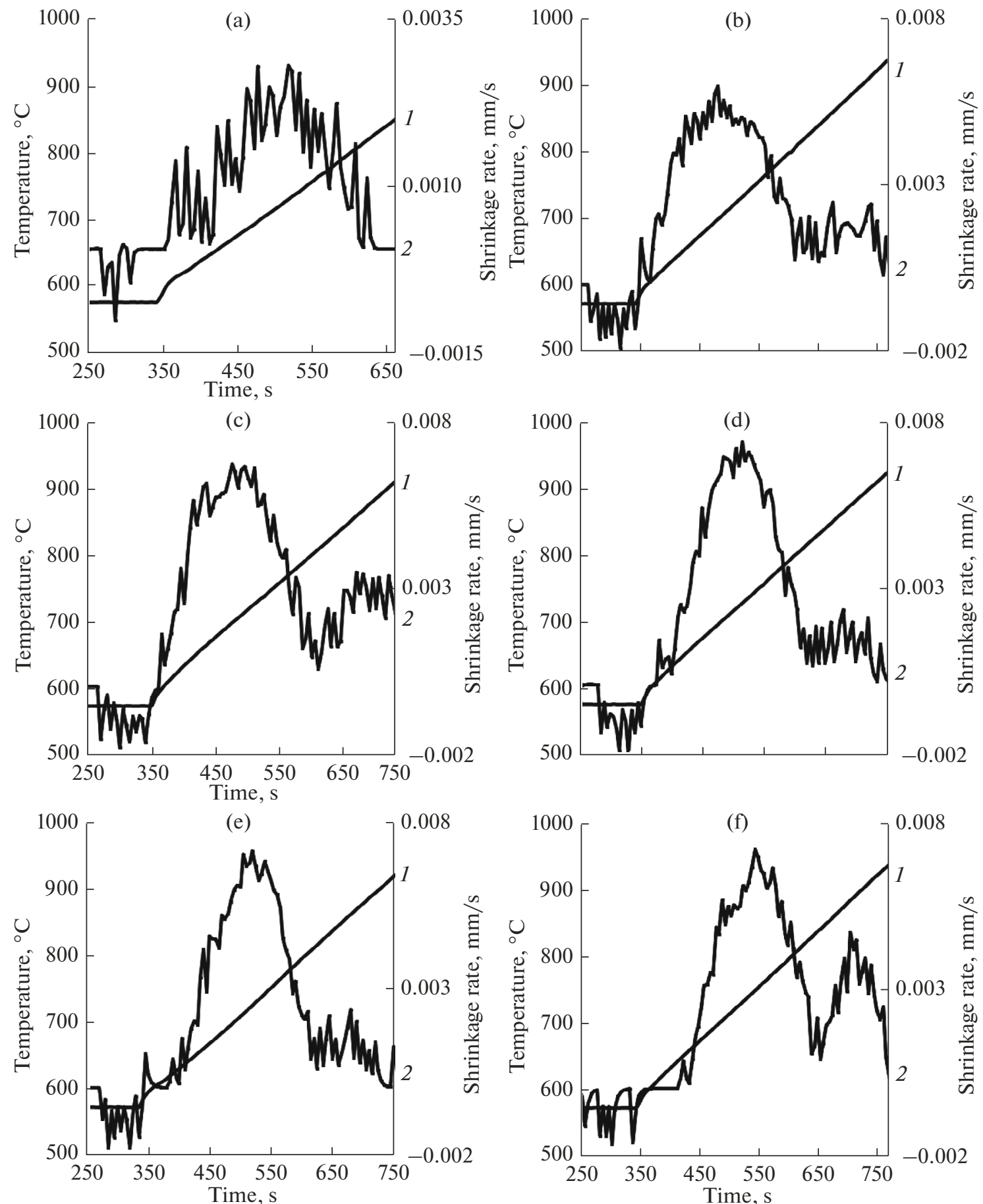

Fig. 5. Shrinkage rate $S$ and sintering temperature $t$ as functions of heating/sintering time for the $\mathrm{Na}_{x} \mathrm{Sr}_{1}-2{ }_{2} \mathrm{Nd}_{x} \mathrm{MoO}_{4}$ samples with $x=$ (a) 0 , (b) 0.1, (c) 0.2 , (d) 0.3, (e) 0.4, and (f) 0.5: (1) sintering temperature, (2) shrinkage rate.

Table 3. Sintering conditions and characteristics of the $\mathrm{Na}_{x} \mathrm{Sr}_{1-2 x} \mathrm{Nd}_{x} \mathrm{MoO}_{4}$ ceramic samples

\begin{tabular}{c|c|c|c|c|c|c}
\hline \multicolumn{1}{c|}{$x$} & $P_{\max }, \mathrm{MPa}$ & $t_{\max },{ }^{\circ} \mathrm{C}$ & $S_{\max } \times 10^{3}, \mathrm{~mm} / \mathrm{s}$ & $\tau_{\text {sint }}, \mathrm{s}$ & $\rho_{\text {meas }}, \mathrm{g} / \mathrm{cm}^{3}$ & $\rho_{\text {rel }}, \%$ \\
\hline 0 & 67.5 & 872 & 2.74 & 650 & $4.582 \pm 0.008$ & 97.08 \\
0.1 & 67.3 & 985 & 6.99 & 750 & $4.675 \pm 0.015$ & 97.72 \\
0.2 & 68.4 & 941 & 6.66 & 750 & $4.771 \pm 0.009$ & 99.29 \\
0.3 & 69.1 & 942 & 7.28 & 750 & $4.783 \pm 0.025$ & 98.24 \\
0.4 & 69 & 942 & 7.10 & 750 & $4.901 \pm 0.009$ & 98.93 \\
0.5 & 68.5 & 942 & 7.16 & 750 & $4.987 \pm 0.012$ & 98.81 \\
\hline
\end{tabular}




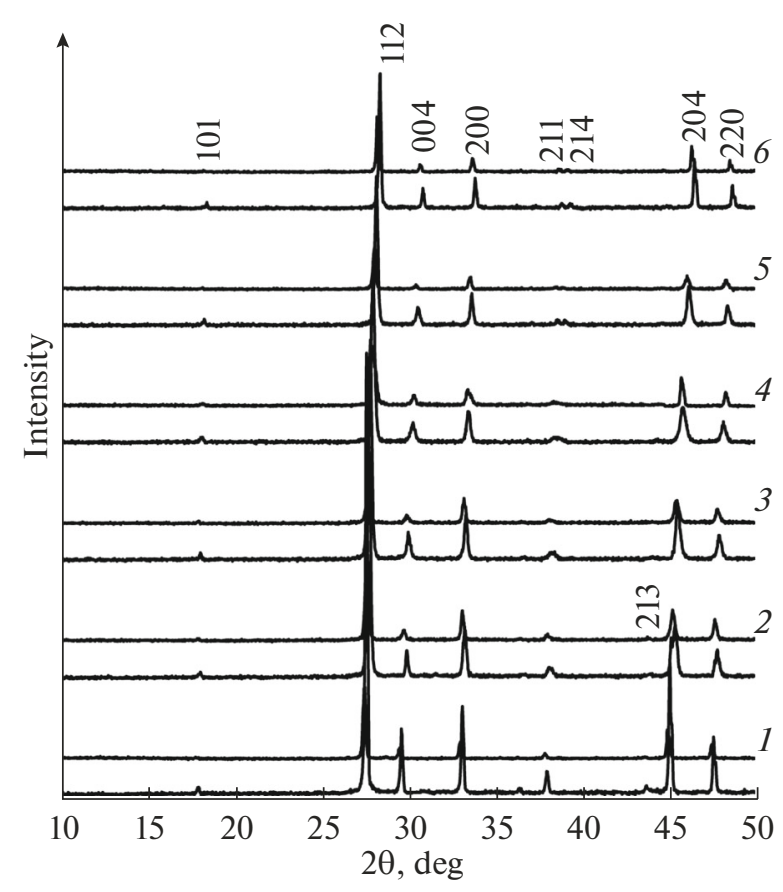

Fig. 6. X-ray diffraction patterns of the $\mathrm{Na}_{x} \mathrm{Sr}_{1}-{ }_{2 x} \mathrm{Nd}_{x}$ $\mathrm{MoO}_{4}$ powders (lower profiles) and ceramics (upper profiles) with $x=(1) 0$, (2) 0.1, (3) 0.2 , (4) 0.3 , (5) 0.4 , and (6) 0.5 .

\section{FUNDING}

This work was supported by the Russian Science Foundation, project no. 16-13-10464: Promising Mineral-Like Ceramic Materials with Improved and Controlled Functional Characteristics: Development, Synthesis, and Characterization.

\section{REFERENCES}

1. Borisevich, V.D., Yan, J., Smirnov, A.Y., Bonarev, A.K., Zeng, S., Sulaberidze, G.A., and Jiang, D., Cascade design for isotopically modified molybdenum as an alternative to zirconium alloys, Chem. Eng. Res. Des., 2017, vol. 128 , pp. $257-264$.

https://doi.org/10.1016/j.cherd.2017.10.018

2. Burakov, B.E., Anderson, E.B., Shabalev, S.I., Strykanova, E.E., Ushakov, S.V., Trotabas, M., Blanc, J.-Y., Winter, P., and Duco, J., The behavior of nuclear fuel in first days of the Chernobyl accident, Mater. Res. Soc. Symp. Proc., 1997, pp. 1297-1308. https://doi.org/10.1557/PROC-465-1297

3. Foreman, M.R.St., An introduction to serious nuclear accident chemistry, Cogent Chem., 2015, vol. 1, no. 1, pp. $1-18$.

http://dx.doi.org/10.1080/23312009.2015.1049111

4. Brinkman, K., Fox, K., Marra, J., Reppert, J., Crum, J., and Tang, M., Single phase melt processed powellite $(\mathrm{Ba}, \mathrm{Ca}) \mathrm{MoO}_{4}$ for the immobilization of Mo-rich nuclear waste, J. Alloys Compd., 2013, vol. 551, pp. 136-142. https://doi.org/10.1016/j.jallcom.2012.09.049
5. Bosbach, D., Rabung, T., Brandt, F., and Fanghänel, T., Trivalent actinide coprecipitation with powellite $\left(\mathrm{CaMoO}_{4}\right)$ : secondary solid solution formation during HLW borosilicate-glass dissolution, Radiochim. Acta, 2004, vol. 92, pp. 639-643.

https://doi.org/10.1524/ract.92.9.639.54976

6. Morozov, V.A., Mironov, A.V., Lazoryak, B.I., Khaikina, E.G., Basovich, O.M., Rossell, M.D., and Van Tendeloo, G., $\mathrm{Ag}_{1 / 8} \mathrm{Pr}_{5 / 8} \mathrm{MoO}_{4}$ : an incommensurately modulated scheelite-type structure, J. Solid State Chem., 2006, vol. 179, no. 4, pp. 1183-1191.

https://doi.org/10.1016/j.jssc.2005.12.041

7. Evdokimov, A.A., Efremov, V.A., Trunov, V.K., Kleinman, I.A., and Dzhurinskii, B.F., Soedineniya redkozemel'nykh elementov. Molibdaty. Vol'framaty (RareEarth Molybdates and Tungstates), Moscow: Nauka, 1991.

8. Hanusa, J., Raman scattering and infra-red spectra of tungstates $\mathrm{KLn}\left(\mathrm{WO}_{4}\right)_{2}$-Family ( $\left.\mathrm{Ln}: \mathrm{La}-\mathrm{Lu}\right)$, J. Mol. Struct., 1984, vol. 114, pp. 471-474.

https://doi.org/10.1016/0022-2860(84)87189-6

9. Kolysh, A.V., Kryukova, A.I., and Korshunov, I.A., Effect of component solubility on the formation of rare-earth and divalent metal (calcium, strontium, and barium) molybdates, Radiokhimiya, 1973, vol. 15, no. 1 , pp. 3-7.

10. Kolysh, A.V., Kryukova, A.I., and Korshunov, I.A., Effect of the nature of the solvent on the formation of mixed crystals of promethium with alkaline-earth molybdates in a melt: II. Cocrystallization of promethium with calcium molybdate, Radiokhimiya, 1970, vol. 12, no. 6, pp. 814-818.

11. Kolysh, A.V., Kryukova, A.I., and Korshunov, I.A., Effect of the nature of the solvent on the formation of mixed crystals of promethium with alkaline-earth molybdates in a melt: I. Cocrystallization of promethium with calcium molybdate, Radiokhimiya, 1970, vol. 12 , no. 6, pp. 808-814.

12. Pages, M. and Freundlich, W., Phases of scheelite structure in the neptunium molybdate and sodium or lithium molybdate systems, J. Inorg. Nucl. Chem., 1972, vol. 34, no. 9, pp. 2797-2801.

https://doi.org/10.1016/0022-1902(72)80584-0

13. Lee, M.R. and Mahe, P., Molybdates et tungstates d'uranium IV et de sodium, C. R. Acad. Sci. Paris, 1974, vol. 279 , no. 26 , pp. $1137-1170$.

14. Tabuteau, A. and Pages, M., Identification and crystal chemistry of double molybdates of alkali metals $(\mathrm{K}, \mathrm{Rb}$, $\mathrm{Cs})$ and transuranium elements ( $\mathrm{Np}, \mathrm{Pu}, \mathrm{Am})$, J. Inorg. Nucl. Chem., 1980, vol. 42, no. 3, pp. 401-403. https://doi.org/10.1016/0022-1902(80)80015-7

15. Tabuteau, A., Pages, M., and Freundlich, W., Sur les phases de structure scheelite dans les systèms molybdate de plutonium-molybdate de lithium ou sodium, Mater. Res. Bull., 1972, vol. 7, no. 7, pp. 691-697. https://doi.org/10.1016/0025-5408(72)90058-X

16. Basovich, O.M., Khaikina, E.G., Solodovnikov, S.F., and Tsyrenova, G.D., Phase formation in the systems $\mathrm{Li}_{2} \mathrm{MoO}_{4}-\mathrm{K}_{2} \mathrm{MoO}_{4}-\mathrm{Ln}_{2}\left(\mathrm{MoO}_{4}\right)_{3}(\mathrm{Ln}=\mathrm{La}, \mathrm{Nd}, \mathrm{Dy}$, $\mathrm{Er})$ and properties of triple molybdates $\operatorname{LiKLn}_{2}\left(\mathrm{MoO}_{4}\right)_{4}$, J. Solid State Chem., 2005, vol. 178, no. 5 , pp. $1580-1588$.

https://doi.org/10.1016/j.jssc.2004.12.016 
17. Basovich, O.M., Khaikina, E.G., Vasil'ev, E.V., and Frolov, A.M., Phase formation in $\mathrm{Li}_{2} \mathrm{MoO}_{4}-$ $\mathrm{Rb}_{2} \mathrm{MoO}_{4}-\mathrm{Ln}_{2}\left(\mathrm{MoO}_{4}\right)_{3}$ systems and properties of $\mathrm{LiRbLn}_{2}\left(\mathrm{MoO}_{4}\right)_{4}$, Zh. Neorg. Khim., 1995, vol. 40, no. 12 , pp. $2047-2051$.

18. Morozov, V.A., Lazoryak, B.I., Smirnov, V.A., Mikhailin, V.V., Basovich, O.M., and Khaikina, E.G., Crystal structures and luminescence properties of ternary molybdates $\mathrm{LiMNd}_{2}\left(\mathrm{MoO}_{4}\right)_{4}(\mathrm{M}=\mathrm{K}, \mathrm{Rb}, \mathrm{Tl})$, Russ. J. Inorg. Chem., 2001, vol. 46, no. 6, pp. 873-879.

19. Basovich, O.M. and Khaikina, E.G., Synthesis and characterization of lithium thallium rare-earth ternary molybdates, Zh. Neorg. Khim., 1994, vol. 39, no. 9, pp. 1419-1420.

20. Szillat, H. and Müller-Buschbaum, Hk., Synthese und Kristallstructur von $\mathrm{KCuHoMo}_{4} \mathrm{O}_{16}, Z$. Naturforsch., 1994, vol. 49, pp. 350-354.

21. Müller-Buschbaum, Hk. and Gallinat, St., Synthese und Röntgenstrukturanalyse von $\mathrm{KCuGd}_{2} \mathrm{Mo}_{4} \mathrm{O}_{16}$ und $\mathrm{KCuTb}_{2} \mathrm{Mo}_{4} \mathrm{O}_{16}, Z$. Naturforsch., 1995, vol. 50, pp. 1794-1798.

22. Klevtsova, R.F., Vasil'ev, A.D., Glinskaya, L.A., Kruglik, A.I., Kozhevnikova, N.M., and Korsun, V.P., Crystal structure of the $\mathrm{Li}_{3} \mathrm{Ba}_{2} \mathrm{Ln}_{3}\left(\mathrm{MoO}_{4}\right)_{8}(\mathrm{Ln}=\mathrm{Gd}$, Tm $)$ ternary molybdates, Zh. Strukt. Khim., 1992, vol. 33, no. 3, pp. 126-130.

23. Achary, S.N., Patwe, S.J., Mathews, M.D., and Tyagi, A.K., High temperature crystal chemistry and thermal expansion of synthetic powellite $\left(\mathrm{CaMoO}_{4}\right)$ : a high temperature X-ray diffraction (HT-XRD) study, $J$.
Phys. Chem. Solids, 2006, vol. 67, pp. 774-781. https://doi.org/10.1016/j.jpcs.2005.11.009

24. Binoy, K.M., Hrudananda, J., Asuvathraman, R., and Govindan Kutty, K.V., Electrical conductivity and thermal expansion behavior of $\mathrm{MMoO}_{4}(\mathrm{M}=\mathrm{Ca}, \mathrm{Sr}$ and Ba), J. Alloys Compd., 2015, vol. 640, pp. 475-479. https://doi.org/10.1016/j.jallcom.2015.04.054

25. Pang, L.-X., Zhou, D., Cai, C.-L., and Liu, W.-G., Infrared spectroscopy and microwave dielectric properties of ultra-low temperature firing $\left(\mathrm{K}_{0.5} \mathrm{La}_{0.5}\right) \mathrm{MoO}_{4}$ ceramics, Mater. Lett., 2013, vol. 92, pp. 36-38. https://doi.org/10.1016/j.matlet.2012.10.082

26. Pang, L.-X., Zhou, D., Guo, J., Yue, Z.-X., and Yao, X., Microwave dielectric properties of $\left(\mathrm{Li}_{0.5} \mathrm{Ln}_{0.5}\right) \mathrm{MoO}_{4}$ $(\mathrm{Ln}=\mathrm{Nd}, \mathrm{Er}, \mathrm{Gd}, \mathrm{Y}, \mathrm{Yb}, \mathrm{Sm}$, and Ce) ceramics, J. Am. Ceram. Soc., 2015, vol. 98, no. 1, pp. 130-135. https://doi.org/10.1111/jace.13247

27. Hérisson de Beauvoir, T., Molinari, F., Chung-Seu, U.C., Michau, D., Denux, D., and Josse, M., Densification of $\mathrm{MnSO}_{4}$ ceramics by cool-SPS: evidences for a complex sintering mechanism and magnetoelectric coupling, J. Eur. Ceram. Soc., 2018, vol. 38, no. 11, pp. 3867-3874.

https://doi.org/10.1016/j.jeurceramsoc.2018.04.005

28. Herisson de Beauvoir, T., Sangregorio, A., Bertrand, A., Payen, C., Michau, D., Chunga, U.-C., and Josse, M., Cool-SPS stabilization and sintering of thermally fragile, potentially magnetoelectric, $\mathrm{NH}_{4} \mathrm{FeP}_{2} \mathrm{O}_{7}$ (CJ-3:IL04), Ceram. Int. (in press). https://doi.org/10.1016/j.ceramint.2018.12.103 